Hardecker, D.J.K. \& Haun, D.B.M. (2020). Approaching the Development of Hurt Feelings in Chhildhood. New Ideas in Psychology, 59, XXX.

The published version can be found at: https://doi.org/10.1016/j.newideapsych.2020.100796

\title{
Approaching the Development of Hurt Feelings in Childhood
}

\author{
David J. K. Hardecker ${ }^{1,2}$, Daniel B. M. Haun ${ }^{1,2}$ \\ ${ }^{1}$ Department of Comparative Cultural Psychology, Max Planck Institute for Evolutionary \\ Anthropology, Deutscher Platz 6, 04103 Leipzig, Germany \\ ${ }^{2}$ Department of Early Child Development and Culture, Leipzig University \\ Jahnalle 59, H2, 04109 Leipzig, Germany
}

Corresponding author:

David J. K. Hardecker

david hardecker@eva.mpg.de

Funding source:

The first author has received a scholarship from the Heinrich-Böll-Foundation, Germany. 


\begin{abstract}
When do hurt feelings develop? In this paper, we want to set the stage for empirical investigations that can answer this neglected question. Thus, we present an integrative theory of hurt feelings according to which hurt feelings in their narrow sense consist of (a) a primary appraisal of an illegitimate devaluation, (b) a secondary appraisal of low controllability, (c) an action tendency to withdraw, and (d) the communicative function to signal that one has been wronged, and is expecting reparation. We argue that sulking behavior can be used as an approach to studying hurt feelings in young children because the same appraisals are assumed to underlie sulking. Thus, we review what is known about pouting as a facial expression and sulking behavior. After discussing the ontogeny of two important eliciting situations of hurt feelings_-abandonment and sibling favoritism, we preliminarily conclude that relevant behaviors are not present in jealousy experiments that involve a situation of discrimination and that hurt feelings seem not yet present in the Ainsworth Strange Situation at twelve months of age. Finally, we review empirical studies on shame, pride, guilt and social norms because they relate to the same motivational topic of legitimacy and social evaluation. In summary, this review suggests that it is likely that sulking behavior and thus hurt feelings in their narrow sense begin to develop at the end of the second year, together with other self-conscious emotions, but that empirical investigations are strongly needed.
\end{abstract}

Keywords: hurt feelings; attachment; emotional development; guilt; shame; anger 


\section{Approaching the Development of Hurt Feelings in Childhood}

Imagine a child being very excited about a novel toy that they got from their parents.

When they show the toy to their friends the next day, the friends make fun of it. The child feels hurt. How old do you imagine that child to be? And thinking a step further: what is the youngest age at which you would attribute hurt feelings to a child in general? In other words, at what age do children become capable of feeling hurt? Although there are a couple of developmental studies that have investigated hurt feelings (Celik, 2015; MacEvoy, 2006; Rumbaugh Whitesell \& Harter, 1996; Saarni, 1997; Weiner \& Handel, 1985), this particular question has not been addressed.

By "hurt feelings" or synonymously "feeling hurt" we refer to a negative affective experience that occurs most frequently within social relationships in situations in which one typically is or feels abandoned, ignored, criticized, teased, or betrayed by someone valued (Feeney, 2005; Leary, Springer, Negel, Ansell, \& Evans, 1998; Vangelisti, Young, Carpenter-Theune, \& Alexander, 2005). (A proper definition will be developed later.) From one of the few studies dedicated to hurt feelings in children, we know that seven- to ten-year-old children in western societies feel hurt in similar situations as adults: broken promises, sibling favoritism, teasing, criticism, but also being yelled at, being punished or not allowed to do something (Mills, Nazar, \& Farrell, 2002). Given the ubiquity of those situations, hurt feelings seem to be central for children's lives. They appear to be an emotion that relates to experiences such as ostracism, bullying and discrimination. As is true for shame, understanding hurt feelings certainly will inform psychopathologi- 
cal development (Ferguson, 2005; Mills, 2005) and has societal relevance because severe hurt feelings can motivate criminal behavior such as revenge (Frijda, 1994). Recently, evidence has been growing that hurt feelings are a distinct emotion (Feeney, 2005; Leary \& Springer, 2001; Leary \& Leder, 2009). Additionally, we know of at least 24 languages that have a word for feeling hurt (Fontaine, Scherer, \& Soriano, 2013) which indicates the cross-cultural relevance of experiencing hurt feelings in human interaction.

In this paper, we want to address the question: at what age do hurt feelings emerge in childhood? In the first part, we thus present an integrative theory of hurt feelings (Hardecker, 2019) that is derived from the adult literature (Feeney, 2005; Leary et al. 1998; Lemay, Overall, \& Clark, 2012; Vangelisti \& Young, 2000). The theory consists of several components: the appraisal of an illegitimate devaluation, the appraisal of low controllability, the action tendency to withdraw from the situation and the communicative function to signal that one has been wronged, and thus expects reparation. In the second part, we establish sulking behavior as the prototypical and functional behavior that results from hurt feelings and point out its usefulness for studying hurt feelings in young children. We review the literature on pouting and sulking. Furthermore, we review studies that inform us about the ontogenetic emergence of the child's sensitivity to typical antecedent conditions of hurt feelings. Finally, we consider studies that relate to illegitimate devaluation — the primary appraisal of hurt feelings. Taken together, those studies suggest that hurt feelings do not develop before the end of the second year of life. 


\section{The Nature of Hurt Feelings}

What is the nature of hurt feelings? In the following, we delineate a componential theory of hurt feelings as a distinct emotion based on the adult literature on hurt feelings (Hardecker, 2019). Exemplary elicitors of feeling hurt are events in which one is not being listened to, being criticized, being betrayed, abandoned, excluded or falsely accused (Leary et al.,1998; Vangelisti, Young, Carpenter-Theune, \& Alexander, 2005). Those situations are central to self-esteem, the threat to which has long been theorized to lie at the core of feeling hurt (Freud, 1952; Lersch, 1964; Mees, 1992). Leary and colleagues (1998) thus inferred that "relational devaluation - the perception that another individual does not regard his or her relationship with the person to be as important, close, or valuable as the person desires" (p.1225) might cause hurt feelings. This view has been supported by several studies (Leary et al. 1998, Feeney, 2005, Lemay et al., 2012).

Still, relational devaluation might not explain all of hurt feelings. The main response of perpetrators has been found to be apologetic, in case they became aware of the hurt feelings of the victim (Leary et al. 1998). Thus, it seems compelling that another component is also involved: the devaluation must be perceived as illegitimate, unfair or undeserved. This has been assumed by Mees (1992), Shaver, Schwartz, Kirson, and O'connor (1987) and by Vangelisti and Sprague (1998). In a retrospective questionnaire study, Feeney (2005) found that participants indeed reported violations of interpersonal norms (e.g., supportiveness, loyalty, openness and trust) across almost all hurtful events. We agree with Feeney (2005) that such transgressions would often signal devaluation. But we further assume that only when they actually do so, one 
would indeed feel hurt. Thus, we hold that the currently most promising theory is that hurt feelings involve an appraisal of an illegitimate devaluation - the perception that another individual did something which the "victim" thinks is undeserved or inappropriate and which they interpret as signaling that the other individual does not regard them to be as important, close, or valuable as they desired. Our account is in line with a philosophical analysis of hurt feelings (Statman, 2000) and the view of psychotherapists (Dryden, 2007; Haller, 2015). Note that our account does not imply that there is indeed a moral transgression in an objective sense. Consider the following example: A team captain in a sports game is allowed to pick only one more player and does not pick the target child who is his friend. Instead, he chooses the better player. The target child might feel hurt, and thus experience the situation as illegitimate (e.g., due to their normative beliefs regarding friendships) although the team captain did not commit a moral transgression. Importantly, the target child might also experience the situation as devaluing and deserved and might accordingly feel ashamed (Klein, 1991; Lewis, 1995; Sznycer et al. 2016). In case perceived morality would play no role in this situation, the child would probably only feel sad. Thus, this account suggests a possibility to distinguish hurt feelings from shame and sadness.

Centrally, we must distinguish hurt in the sense described so far, that is, in the sense of a core appraisal, from feeling hurt in the sense of an emotion which includes an action tendency, and a social-communicative function (narrow sense). Thus, the first and broad sense is indicated when we have in mind that we can react to ,hurt feelings“ in different ways. L'Abate 
(1977), for example, talks about "anger that is the result of feeling hurt" (p.13) and Shaver,

Schwartz, Kirson, \& O'connor (1987) quote their participants who talked about "hurt [... ] that warrants anger" (p.1082). Both quotes indicate the broad sense of hurt feelings. The narrow meaning, on the other hand, involves a specific way of reacting which has been described as silencing (Freud, 1952) and to "close direct channels of communication" (Dryden, 2007). In support of these claims, Vangelisti and Young (2000) found that individuals who reported a hurtful instance tended indeed to relationally distance themselves from the perpetrator. We assume, that this action tendency is caused by an appraisal of powerlessness, which has been shown to be part of hurt feelings by Feeney (2004), Lemay et al. (2012) and Hareli and Hess (2008). The action tendency might fulfill a particular communicative function: "to indirectly show the other person how you feel" (Dryden, 2007), thus, trying to elicit guilt in the perpetrator and thus making him apologize or repair in one or the other way. This is what perpetrators indeed frequently do (Leary et al., 1998).

This account also allows to distinguish hurt feelings (in the narrow sense) from anger. Whereas anger involves hurt feelings in their broad sense (Ellsworth \& Smith, 1988; Lazarus, 1991; Leary, Twenge, \& Quinlivan, 2006; Smith \& Lazarus, 1993), anger has been found to be associated with high controllability (Lemay et al., 2012), the tendency to attack, and with the social function to force another person to change his or her behavior (Frijda, 1986; Fischer \& Roseman, 2007; Fischer \& Manstead, 2009). 
Taken together, we have distinguished a broad and a narrow concept of feeling hurt based on linguistic usage. The broad concept is defined by an appraisal of an illegitimate devaluation alone. The narrow concept is further defined by an appraisal of powerlessness, an action tendency to withdraw and a communicative function that potentially elicits guilt and thus reparation from the "perpetrator". In the following, we focus on hurt feelings in their narrow sense which we have construed as a distinct emotional phenomenon and which might thus be more easily approached.

\section{The Ontogenetic Beginnings of Hurt Feelings}

When are children capable of feeling hurt? Some authors may challenge the worth of this research question altogether. Campos and Barrett (1987) have prominently criticized the assumption that "emotions are reified wholes, which emerge at some point in development. That is, each emotion, as a whole, is absent until the point in development, when critical conditions are met" (p.557). According to this paradigm, there are only emotion families and not invariant links between emotions and particular emotion components, such as appraisals, action tendencies, physiological processes, emotion expression, and adaptive functions. We argue that failing to postulate invariant features for emotions, immunizes a theory: it can, accordingly, not be falsified. Here, we follow the work of Lazarus (1991), Fischer and Tangney (1995), and Frijda (2007), suggesting that the invariant core of an emotion is its appraisal which determines in which way a particular situation relates to the needs of an individual together with its action tendency. Such a view still allows for both contextual variation concerning physiological processes, expression and 
behavior as well as for developmental variation. Furthermore, , we might find out empirically that there are different complex forms of hurt feelings at different stages of development, neither being the "true" feelings of hurt (cp. Campos, Walle, \& Dahl, 2010).

One hint comes from interviews conducted by Çelik (2015) in which some school children describe having their feelings hurt in preschool several years prior. But for our particular question, interviews and self-reports seem not very well-suited, because infants and young children cannot verbalize what they feel. Two overlapping observational approaches for this question seem promising in general. The first approach consists of observing sensitivity to common antecedents of a particular emotion. A given antecedent situation can lead to a "multiplicity of emotions" (Campos, Frankel, \& Camras, 2004), but this need not always be the case. Hart and Carrington (2002), for example, showed that six-month-old infants reacted in a notably more negative way when the mother was attending to a doll than when she was attending to a book. Thus, the authors tried to infer jealousy based on sensitivity to a specific kind of situation. The second approach consists of focusing on the emergence of a particular emotional expression or behavior indicative of a certain emotion. In particular, we would need to understand the function of the behavior to be able to classify it as resulting from a particular emotion (Campos et al., 2004). 


\subsection{Sulking Behavior as an Approach to Feeling Hurt}

Sulking behavior typically consists of the following observable features: turning away, physically distancing, gaze avoidance, talking less/becoming silent, lowering the head, crossing arms, pouting face (Hardecker, Schmidt, Haun (2020). We suggest using sulking behavior as an approach for studying hurt feelings in their narrow sense. The following example from an ongoing diary study illustrates why. Two children sitting at the breakfast table are discussing how to hold cups the right way. Suddenly the father says to the son: "You are not able to hold the cup right, because you have spaghetti arms." The son falls silent, crosses his arms, lowers his head and pouts his lips. If we assume that the son feels hurt in this moment, this would mean, according to our theory, that he appraises this insult as devaluing, illegitimate and himself as rather helpless, which makes him fall silent. (Perceiving oneself as helpless does not imply that the resulting behavior has no influence on the other person.) Indeed, the link between feeling hurt and sulking behavior has often been taken for granted (Lersch, 1964; Dryden, 2007), even by cross-cultural researchers such as Eibl-Eibesfeldt (1989).

In support of such an approach, hypotheses about sulking that have been independently formulated from hypotheses about feeling hurt largely reflect the latter, as can be seen in Table 1. Mendell (2002), for example, suggested that sulking results when children: (a) feel unfairly treated, and/or (b) feel humiliated (c) by a person more powerful than the child itself. Concerning the function of sulking, she states that "by withdrawing, children try to influence the other person until they make it up to the child" (p.189). Sulking, construed in this way, perfectly 
reflects the primary and secondary appraisal of feeling hurt (see Elison \& Harter, 2007 for a discussing humiliation in terms of devaluation), the action tendency of withdrawing, and the social-communicative function that aims at a reparation of the perpetrator.

This view is largely shared by Lazarus (1991). With regard to the primary appraisal, he states that pouting is about being "disappointed by another person from whom more was expected or hoped" and to "feel inadequate and dependent" (p. 228). We would add that the felt inadequacy is not accepted by the child; otherwise, it would not communicate reproach as suggested by Lazarus. He also agrees with a low controllability ("the coping potential is unfavorable"(p. 228)), but in his eyes because of a "threat (and its anxiety) what an uninhibited expression of anger is thought to produce - namely, retaliation and loss of succor"(p. 228). Here, Lazarus seems to miss the point that children often do the very opposite of what he suggests: they threaten to end the relationship with their caregiver (Eibl-Eibesfeldt, 1989) by saying, for example, "I won't play with you anymore" (p. 499). This threat contradicts the claim that pouting involves fear of loss of succor. We thus favor the hypotheses of Mendell (2002) and Eibl-Eibesfeldt (1989) that children sulk to influence the other person until he/she makes it up to the child by signaling a threat to end the relationship. We further suggest it is reasonable that by sulking, children are sometimes not aiming at reparation, but at getting their own way. The former might be the developmental precursor of the latter. 
Table 1. Overview of Theories on Sulking and Theories on Hurt Feelings and Sulking

\begin{tabular}{|c|c|c|c|c|c|}
\hline Author & Emotion & $\begin{array}{l}\text { Primary } \\
\text { Appraisal }\end{array}$ & $\begin{array}{l}\text { Secondary } \\
\text { Appraisal }\end{array}$ & Behavior & $\begin{array}{l}\text { Communicative signal of Be- } \\
\text { havior and/or Intended Effect }\end{array}$ \\
\hline $\begin{array}{l}\text { Hardecker } \\
(2019)\end{array}$ & $\begin{array}{l}\text { Hurt Feelings } \\
\text { (in their nar- } \\
\text { row sense) }\end{array}$ & $\begin{array}{l}\text { Illegitimate } \\
\text { devaluation } \\
\text { (Hurt feelings } \\
\text { in their broad } \\
\text { sense) }\end{array}$ & Powerlessness & $\begin{array}{l}\text { Crying, } \\
\text { Sulking }\end{array}$ & $\begin{array}{l}\text { Threat to end the relationship, } \\
\text { Justice by means of punishment } \\
\text { or reparation }\end{array}$ \\
\hline $\begin{array}{l}\text { Dryden }(2007, \\
\text { p.11,18) }\end{array}$ & Hurt Feelings & $\begin{array}{l}\text { "when you } \\
\text { consider this } \\
\text { disapproval to } \\
\text { be undeserved" }\end{array}$ & & Sulking & $\begin{array}{l}\text { "to shut down direct channels of } \\
\text { communication with the person } \\
\text { about whom you have made } \\
\text { yourself feel hurt. [...] your goal } \\
\text { is to indirectly show the other } \\
\text { person how you feel" }\end{array}$ \\
\hline $\begin{array}{l}\text { Mendell (2002, } \\
\text { p.189) }\end{array}$ & Humiliation & $\begin{array}{l}\text { "when they feel } \\
\text { unfairly treated } \\
\text { and humiliated" }\end{array}$ & $\begin{array}{l}\text { "by people more } \\
\text { powerful than } \\
\text { themselves" }\end{array}$ & Sulking & $\begin{array}{l}\text { "influence the other person un- } \\
\text { til they make it up to the child" }\end{array}$ \\
\hline $\begin{array}{l}\text { Eibl-Eibesfeldt } \\
(1989, \text { p. 560) }\end{array}$ & Hurt Feelings & & & $\begin{array}{l}\text { Pouting, } \\
\text { Sulking }\end{array}$ & $\begin{array}{l}\text { "threatening to break off con- } \\
\text { tact" }\end{array}$ \\
\hline $\begin{array}{l}\text { Lazarus, } \\
(1991, \text { p. 228) }\end{array}$ & & $\begin{array}{l}\text { "been disap- } \\
\text { pointed by an- } \\
\text { other person } \\
\text { from whom } \\
\text { more was ex- } \\
\text { pected or } \\
\text { hoped" }\end{array}$ & $\begin{array}{l}\text { "feel inadequate } \\
\text { and dependent"; } \\
\text { "the coping po- } \\
\text { tential is unfavor- } \\
\text { able"; } \\
\text { "threat (and its } \\
\text { anxiety) what an } \\
\text { uninhibited ex- } \\
\text { pression of anger } \\
\text { is thought to pro- } \\
\text { duce - namely, re- } \\
\text { taliation and loss } \\
\text { of succor" }\end{array}$ & Pouting & $\begin{array}{l}\text { "expresses not only reproach, } \\
\text { but neediness", "to force (...) to } \\
\text { pay attention"" }\end{array}$ \\
\hline $\begin{array}{l}\text { Lersch }(1961, \\
\text { p.249) }\end{array}$ & $\begin{array}{l}\text { Verletzt, } \\
\text { Gekränkt } \\
\text { [Hurt Feel- } \\
\text { ings] }\end{array}$ & $\begin{array}{l}\text { "Wo dem Gel- } \\
\text { tungsstreben } \\
\text { seine Erfüllung } \\
\text { versagt wird" } \\
\text { [where striving } \\
\text { for standing is } \\
\text { denied] }\end{array}$ & & Sulking & $\begin{array}{l}\text { „Ein Sich-zurückziehen, wobei } \\
\text { man aber immer noch auf die } \\
\text { Welt hinschielt und eigentlich } \\
\text { darauf wartet, } \underline{\text { daß }} \text { sie einen } \\
\text { wieder zurückruft“ [ With- } \\
\text { drawal, during which one is still } \\
\text { squinting at the world waiting } \\
\text { for being called back] }\end{array}$ \\
\hline
\end{tabular}

Note that sulking and pouting are often used synonymously; we refer with "sulking" to the general behavior and with pouting only to the facial expression. One row contains one theory and the terms and quotes therein. Empty cells mean that the author has not said anything about it. 
Against studying hurt feelings through the framework of sulking, one might object that in the study of Mills et al. (2002) children have reported different reactions (argue/defend, express anger/disappointment [slammed door, silent treatment], hide feelings and cry). We hypothesize that if one could observe these behaviors, most of them could be identified as sulking (silent treatment, arguing/defending [depending on their prosody]), due to their interpersonal function or equifinality (cf. Walle, Reschke, Camras, \& Campos, 2017).

Furthermore, we do not claim that hurt feelings necessarily lead to sulking behavior, but only that sulking behavior (not the facial expression of pouting alone) is unambiguously indicative of hurt feelings in their narrow sense. This is not true for crying, which is also a typical result of hurt feelings; in contrast to sulking, though, it seems to be a ratherambiguous indicator because it indicates several other emotions (Vingerhoets \& Bylsma, 2016). However, it seems promising to explore whether one specific type of crying (Hendriks, Nelson, Cornelius \& Vingerhoets, 2008; Williams \& Morris, 1996) could be related to hurt feelings.

One might further be skeptical about sulking as an approach and question that sulking needs to be the consequence of an illegitimate devaluation. It might simply be the consequence of not getting one's way from someone. We hypothesize that, from early on in development, children experience violations of their autonomy as disrespectful and thus devaluing and illegitimate (cf. Barkow, 1975; Bischof-Köhler, 2011).

In the following, we review what we know about sulking behavior and pouting. Henceforth, by sulking we refer to the general behavior described thus far, whereas with pouting we re- 
fer to the facial expression only (described in detail below). Pouting alone is not a clear indicator of feeling hurt, as it often elicits mere empathy not guilt.

\subsection{Pouting and Sulking}

Pouting, the facial expression of sulking behavior, is shown from the earliest days on by human infants. It has been studied by Oster (2005) using BabyFACS, the Facial Action Coding System for infants and young children and consists of AU17 (lower lip raised) and AU8 (upper lip pulled down and tightened). The upper face components correspond to expressions of anger or sadness (brows lowered or obliquely raised). Oster found that pouts in young infants are also associated with open eyes and gazing at the caregiver, and thus not with withdrawal. In the first months, pouts can be seen in the context of crying, in general situations of frustration. Thus, according to our view, this early pouting should not be seen as the reaction to a specific class of events yet, but rather the expression of general distress (Sroufe, 1997). Such pouting faces seem different from sulking behavior as described above, and not restricted to feeling hurt.

Eibl-Eibesfeldt (1989, p.566), on the other hand, documents a case of sulking behavior in the Yanomami, an indigenous people of Venezuela. A mother is sitting with her 3-month-old on the ground. First, she neglects her contact-seeking infant. When she turns towards the infant, the infant starts protesting and lies down on the ground. Eibl-Eibesfeldt (1989) identified sulking in this case solely on the basis of one feature: turning away. No pouting expression is visible. He hypothesized that sulking behavior is an innate strategy which is already used by the 2-month-old 
infant. Similarly, with approximately eight- to nine-months, pouting also appears in Still-Face situations, in which mothers do not react to the behavior of the baby as well as in the context of fear (Oster, 2005). Tronick and colleagues (Tronick, Als, Adamson, Wise, \& Brazelton, 1978) reported that in such Still Face situations "the baby would arch his or her back away from the mother as if he had not forgiven her the previous insult" (p.10). But the accepted explanation is that the child tries to regulate the source of the negative affect by physically turning away (as in the still face itself). The difference between physically turning away and turning away as part of sulking is that the child would let the caregiver soothe him/her when it is merely turning away for regulation of negative affect. In contrast, the child would not let the caregiver soothe him/her when the behavior is part of sulking. Future studies might investigate whether children have shown a pouting face while turning away, which would be a strong argument for the presence of sulking, as we have described it.

\subsection{Typical Situations That Elicit Hurt Feelings}

What are situations that elicit feeling hurt in older children and adults, to which even younger children might be sensitive? Based on Leary et al. (1998) and Mills et al. (2002) abandonment and sibling favoritism are potentially two early candidates. Shaver, Mikulincer, Lavy, and Cassidy (2009) theorized that feeling hurt results from “(a) appraising a partner's actions, inaction, or words as endangering one's sense of attachment security, and (b) appraising oneself as needing to maintain or restore such a sense" (p.101). Attachment researchers might thus argue that feeling hurt emerges when attachment relationships reach the status of goal-directedness and 
thus might be observable in the Ainsworth Strange Situation at 12 months of age in which children are abandoned by their mother. However, both Bowlby (1980) and Ainsworth, Blehar, Waters, and Wall (1978) did not mention feeling hurt or sulking in their writing. Clearly, insecurelyavoidant children seem to withdraw after reunion with their mother: they either ignore the caregiver upon their return or show an ambivalent tendency between approaching and turning away. This is in line with the action tendency of feeling hurt, as discussed above, and also with sulking behavior. Nonetheless, the commonly accepted interpretation is that the children try to mask their separation distress as a means of staying close to the caregiver, and not being rejected again (Sroufe, 2000). Bowlby (1980), in general, spoke of anxiety - not feeling hurt - resulting from insecurity. Shaver, Mikulincer, Lavy, and Cassidy (2009) thus remain unclear as to the difference between anxiety and feeling hurt. This is not to say that feeling hurt has nothing to do with attachment relationships. Rather, the fundamental issue of attachment security does not seem to lie at the heart of feeling hurt. The crucial difference between the avoidant child in the Strange Situation and a child who feels hurt would be the following: the child who feels hurt signals the caregiver that he/she has been wronged, and temporarily breaks contact. The avoidant child, on the other hand, behaves quietly and does not signal distress in order to remain in contact. However, this conclusion is only preliminary and intended to provoke and orient empirical work. The same is true for the following discussion.

Children report that sibling favoritism elicits feeling hurt; this occurs early in ontogeny (Mills et al., 2002). Sibling favoritism has been studied empirically within the framework of jeal- 
ousy. Children typically feel jealous when an important relationship is threatened (Panksepp, 2010) which in young children and in the case of sibling favoritism can simply mean that a sibling receives the attention or care of a parent. This situation can, at the same time, be experienced as devaluing and thus hurtful. The question is: do studies on jealousy suggest anything that could indicate hurt feelings? Hart and Carrington (2002) showed that already six-month-old babies reacted more negatively in a condition in which their mothers attended to a baby doll in contrast to situations in which she attended to a music book. In a follow-up study, Hart and colleagues (Hart, Carrington, Tronick, \& Carroll, 2004) showed that, in the jealousy condition (baby doll), sixmonth-olds showed more approach (involving gaze toward the mother, approach posture and facial affect of interest) as well as more overall negativity in contrast to a face-to-face-play condition and a Still-Face condition. We interpret these results as showing that children are indeed affected by their mother attending to another child; however, they are presumably always motivated to regain the mother's attention and care. Hurt feelings as a distinct emotional reaction would, on the other hand, involve at least moments of breaking contact/avoidance (McLaren \& Solomon, 2008, 2010; Vangelisti \& Young, 2000). Accordingly, these studies seem to indicate jealousy but rather not hurt feelings - at least not in their narrow sense.

So far, our review of past literature tentatively suggests that children develop the capacity to feel hurt in its narrow sense no earlier than the second part of the second year of life. 


\subsection{Insights from research on the development of shame and pride}

Holodynski and Friedlmeier (2006) distinguish between emotions that are based on goalreaching or efficacy of an action, which involves joy, anger and disappointment, from those that are based on the evaluation of the action by other individuals (which especially include pride and shame). According to these researchers, by two years of age the positive social approval of a successful action transforms joy into pride; disapproval transforms disappointment into shame and as we will argue, feeling hurt. Nonetheless, goal-reaching in young infants is often a social affair: caregivers regularly prohibit actions that would lead to unacceptable outcomes and may thus hurt the child's feelings, at least in a preliminary form.

As pride and shame also relate to (de-)valuation, it might be fruitful to ask what has been found out about the ontogenetic onset of these emotions? Certainly, three-year-old children show pride and shame as indicated by Lewis, Alessandri, and Sullivan (1992). The authors confronted three-year-old children with tasks of various difficulties. They were asked to do puzzles, an imitation task and a throwing game. Success/failure, as well as pride and shame reactions, were coded as nonverbal behaviors. Children showed both emotional reactions only in the expected situations: shame only when they failed, pride only when they succeeded.

Stipek, Recchia, and McClintic (1992) conducted several studies to examine children's development of self-evaluation and thus learn more about shame and pride. In one study, they compared children's reactions to watching an experimenter completing a task versus completing a task themselves. From 22 months of age onwards, children started to look up more to 
the experimenter when they themselves achieved a task than when the experimenter did so. Crucially, children did not differ with respect to smiling. In a free-play situation with the child and the mother, nearly half of the 22- to 39-month-olds called their mother's attention to at least one achievement, whereas only $14 \%$ of the 13 to 21 -month-olds did. The authors conclude that beginning with two years of age, children have developed a desire for social recognition.

In another study, two- to five-year-olds' reactions to success and failure and the effects of praise were investigated. Children had to do moderately challenging tasks either in a success-condition or a failure condition. In the latter, it was impossible to complete the task. Children of all ages in the success-condition were more likely to comment on their success, to smile, and to show an open body posture (e.g., head up) than children in the failure condition. Children who did not accomplish the tasks were more likely to look or turn away from the experimenter than children who succeeded; they also showed a much more closed posture.

On the whole, then, leading authors (Stipek et al., 1992, Holodynski \& Friedlmeier, 2006) agree on the view that until 24 months children are motivated for efficacy without self-evaluative reactions (pride, shame). Based on the self-other-distinction and their developing a normative understanding of what is right and good and a motivation for being evaluated positively by the caregivers, children from 24 months onward start to seek approval and avoid disapproval (Botto \& Rochat, 2018). Children then start to react with pride when they succeed and with shame when they fail. Nonetheless, there is variance with regard to the exact age and also, presumably, a more gradual transition: In the study of Stipek et al. (1992), several children showed pride and shame 
reactions before two years of age (Draghi-Lorenz, Reddy, \& Costall, 2001). According to our view, children should also feel hurt when they do not accept their failure and appraise the event as inappropriate (e.g., unfair, undeserved). Thus, some children should feel shame in the failurecondition, but some should also feel hurt, especially when their failure is caused by the interference of another individual. In line with this prediction, the study reported above found that after 32 months of age, children were much more likely to pout/frown after failure than after success. Unfortunately, the different facial movements of the pout/frown category were not carefully distinguished, although some facial movements (e.g., pushing one or both lips forward) are likely to indicate sulking, others (e.g., rolling lips inward, lowering corners of mouth) are indicative of shame (Holodynski \& Friedlmeier, 2006).

At what age did children first react with frowning/pouting in the study of Stipek et al. (1992)? In the third year of life, 5-10\% reacted with frowning/pouting. Until the age of four, frowning/pouting as a reaction to failing increased to $45 \%$, in the fifth year there was a slight decrease.

These data help us in two ways. First, they provide an idea of when hurt feelings could develop. Second, they support our claim that it is worth investigating whether children can be reliably said to have either a shame expression or a sulking expression.

\subsection{The development of the appraisal of wrongness}


Part of the primary appraisal is perceiving the action not only as devaluing but as wrong, unfair or inappropriate. As far as we know, children begin to understand social norms with two years of age (Rakoczy \& Schmidt, 2013). With three years of age children understand distributive fairness. However, they do not act accordingly until eight years of age, when their own desires are at stake (Blake, McAuliffe, \& Warneken, 2014). That means we must be careful with respect to the interpretation of moral motivation in children. It could also be the case that young children act based on an obligation that is not yet normative but is a mere need-based demand. On the other hand, studies on the development of guilt have found that children migth feel guilt beginning with either two or three years-of-age (Cole, Barrett, \& Zahn-Waxler, 1992; Drummond, Hammond, Satlof-Bedrick, Waugh, \& Brownell, 2017; Hepach, Vaish, \& Tomasello, 2017; Vaish, Carpenter, \& Tomasello, 2016), which is in line with the results on normative development.

According to the discussion in the last section, findings on pride, shame, guilt and social norms point to the onset of hurt feelings and sulking between two and three years of age.

\section{Conclusion}

We have found that that the question when hurt feelings develop in childhood has so far not been addressed. To approach this question, we have presented an integrative theory of hurt feelings in which we distinguish between a broad and a narrow sense of "hurt feelings". According to this account, hurt feelings in their narrow sense are constituted by appraisals of an illegiti- 
mate devaluation and low controllability, an action tendency to withdraw and a communicative display that signals that one has been wronged, and expects reparation. We have posited that the study of sulking is an unambiguous approach to studying hurt feelings construed in this narrow way, and showed that theories on sulking are almost identical to our account of hurt feelings. They involve the same primary appraisal. Further, the characteristics of sulking (e.g., turning away, distancing, talking less or silencing, crossing arms, pouting faces, head lowered) reflect the action tendency of hurt feelings (withdrawing), thereby signaling a threat to break contact and to get one's way or receive an apology. In reviewing empirical findings on sulking, on antecedents of hurt feelings, as well as studies of devaluation and illegitimacy, we have argued that (a) early pouting faces are something different from later sulking behavior, (b) sibling favoritism in the first year of life and abandonment in the Ainsworth Strange Situation with 12- month-olds presumably do not involve hurt feelings (but only attachment motivation and separation distress), and (c) that hurt feelings are likely to co-develop with shame and normative understanding in the third year of life. However, almost all studies we cite are based on research with western populations (Nielsen, Haun, Kärtner, \& Legare, 2017). Furthermore, several claims are highly speculative. Thus, this paper must be read as a first and culturally restricted attempt in preparing and stimulating debate and empirical work on the development of hurt feelings. 


\section{References}

Ainsworth, M. D. S., Blehar, M. C., Waters, E., \& Wall, S. (1978). Patterns of attachment: A psychological study of the Strange Situation. Hillsdale, NJ: Erlbaum.

Barkow, J. H. (1975). Prestige and culture: A biosocial interpretation. Current Anthropology, $16(4), 553-572$.

Bischof-Köhler, D. (2011). Soziale Entwicklung in Kindheit und Jugend: Bindung, Empathie, Theory of Mind. [Social Development in Childhood and Youth: Attachment, Empathy and Theory of Mind]. Suttgart, Germany: Kohlhammer Verlag.

Botto, S. V., \& Rochat, P. (2018). Sensitivity to the evaluation of others emerges by 24 months. Developmental Psychology, 54(9), 1723-1734. doi: 10.1037/dev0000548Bowlby, J. (1980). Attachment and loss. New York: Basic Books.

Blake, P. R., McAuliffe, K., \& Warneken, F. (2014). The developmental origins of fairness: The knowledge-behavior gap. Trends in Cognitive Sciences, 18(11), 559-561. doi: 10.1016/j.tics.2014.08.003.

Campos, J. J., Frankel, C. B., \& Camras, L. (2004). On the nature of emotion regulation. Child Development, 75(2), 377-394. doi: 10.1111/j.1467-8624.2004.00681.x

Campos, J. J., Walle, E. A., \& Dahl, A. (2010). What is missing in the study of the development of jealousy. In: S. L. Hart \& M. Legerstee (pp.312-328): Handbook of Jealousy: Theory, Research, and Multidisciplinary Approaches. West-Sussex, UK: WileyBlackwell. 
Çelik, F. (2015). Entwicklung emotionaler Verletzungssensitivität: Familiäre und schulische De terminanten. [Development of Hurt Sensitivity: Familiar and Academic Determi nants]. University of Wuppertal, Germany: Unpublished doctoral thesis.

Cole, P. M., Barrett, K. C., \& Zahn-Waxler, C. (1992). Emotion displays in two-year-olds during mishaps. Child Development, 63(2), 314-324. doi: 10.1111/j.14678624.1992.tb01629.x

Draghi-Lorenz, R., Reddy, V., \& Costall, A. (2001). Rethinking the development of "nonbasic" emotions: A critical review of existing theories. Developmental Review, 21(3), 263- 304. doi: $10.1006 /$ drev.2000.0524

Drummond, J. D., Hammond, S. I., Satlof-Bedrick, E., Waugh, W. E., \& Brownell, C. A. (2017). Helping the one you hurt: Toddlers' rudimentary guilt, shame, and prosocial behavior after harming another. Child Development, 88(4), 1382-1397. doi: $\underline{10.1111 / \mathrm{cdev} .12653}$

Eibl-Eibesfeldt, I. (1989). Human Ethology. New York, NY: Aldine de Gruyter.

Elison, J., \& Harter, S. (2007). Humiliation: Causes, correlates, and consequences. In J. L. Tracy, R. W. Robins, \& J. P. Tangney (Eds.), The self-conscious emotions: Theory and research (pp. 310-329). New York, NY: The Guilford Press.

Ellsworth, P. C., \& Smith, C. A. (1988). From appraisal to emotion: Differences among unpleasant feelings. Motivation and Emotion, 12 (3), 271-302. doi:

\subsection{7/BF00993115}

Feeney, J. A. (2004). Hurt feelings in couple relationships: Towards integrative models 
of the negative effects of hurtful events. Journal of Social and Personal

Relationships, 21 (4), 487-508. doi: 10.1177/0265407504044844

Feeney, J. A. (2005). Hurt feelings in couple relationships: Exploring the role of attachment and perceptions of personal injury. Personal Relationships, 12(2), 253-271. doi:

10.1111/j.1350-4126.2005.00114.x

Ferguson, T. J. (2005). Mapping shame and its functions in relationships. Child Maltreatment, 10(4), 377-386.

Fischer, A. H., \& Manstead, A. S. (2008). Social functions of emotion. In M. Lewis, M. Haviland-Jones, \& L. Feldman Barret (eds). Handbook of emotions (pp. 456-468). New York, London: The Guilford Press.

Fischer, A. H., \& Roseman, I. J. (2007). Beat them or ban them: The characteristics and social functions of anger and contempt. Journal of Personality and Social Psychology, 93(1), 103. doi: 0.1037/0022-3514.93.1.103

Fischer, K. W., \& Tangney, J. P. (1995). Self-Conscious Emotions and the Affect Revolution:

Framework and Overview. In: K. W. Fischer \& J. P. Tangney (Eds). Self-con scious Emotions: The Psychology of Shame, Guilt, Embarrassment, and Pride (pp. 2-22). New York, NY: Guilford Press.

Freud, S. (1952/1893). Der psychische Mechanismus hysterischer Phänomene [the Psychological Mechanism of Hysterical Phenomena]. In A. Freud (Ed.), Gesammelte Werke [Collected Works], Bd. 1. London: Imago Publishing Co. Ltd. 
Frijda, N. H. (1994). The Lex Talionis: On Vengeance. In S. H. van Goozen,

N. E. Van de Poll, \& J. A. Sergeant (Eds.), Emotions: Essays on Emotion Theory (pp. 263-289). Hillsdale, NJ: Lawrence Erlbaum Associates.

Haller, R. (2015). Die Macht der Kränkung. [The power of hurt feelings]. Salzburg, Austria: Ecowin Verlag.

Hardecker, D. J. K. (2019). The Distinctive Constitution of Feeling Hurt. A Review and a Lazarian Theory. European Psychologist, Advance online publication. https://doi. org/10.1027/1016-9040/a000390.

Hardecker, D. J. K., Schmidt, M. F. H., \& Haun, D. B. M. (2020). Developing a coding system for sulking behavior in young children. Submitted for publication.

Hareli, S., \& Hess, U. (2008). The role of causal attribution in hurt feelings and related

Hart, S. L., \& Carrington, H. A. (2002). Jealousy in 6-month-old infants. Infancy, 3(3), 395-402. doi: 10.1207/S15327078IN0303_6

Hart, S. L., Carrington, H. A., Tronick, E., \& Carroll, S. R. (2004). When infants lose exclusive maternal attention: Is it jealousy? Infancy, 6(1), 57-78. doi: 10.1207/s15327078in0601_3 
Hendriks, M. C. P., Nelson, J. K., Cornelius, R. R., \& Vingerhoets, A. J. J. M. (2008). Why cry ing improves our well-being: An attachment-theory perspective on the functions of adult crying. In A. J. J. M. Vingerhoets, I.Nyklicek, \& J. Denollet (Eds.), Emotion regulation: Conceptual and clinical issues (pp. 87-96). New York, NY: Springer.

Hepach, R., Vaish, A., \& Tomasello, M. (2017). Children's intrinsic motivation to provide help themselves after accidentally harming others. Child development, 88(4), 1251-1264. doi: $10.1111 /$ cdev. 12646

Holodynski, M., \& Friedlmeier, W. (2006). Development of emotions and emotion regulation. New York, NY: Springer Science \& Business Media.

Klein, D. C. (1991). The humiliation dynamic: An overview. Journal of Primary Prevention. 12(2), 93-121.

Lazarus, R. S. (1991). Emotion and adaptation. New York: Oxford University Press.

Leary, M. R., Springer, C., Negel, L., Ansell, E., \& Evans, K. (1998). The causes, phenomenology, and consequences of hurt feelings. Journal of Personality and Social Psychology, 74(5), 1225-1237. doi: 10.1037/0022-3514.74.5.1225

Leary, M. R., \& Springer, C. A. (2001). Hurt feelings: The neglected emotion. In R. M. Kowalski (Ed.), Behaving badly: Aversive behaviors in interpersonal relationships (pp. 151175). Washington, DC: American Psychological Association. Doi: 10.1037/10365006

Leary, M. R., Twenge, J. M., \& Quinlivan, E. (2006). Interpersonal rejection as a determinant of anger and aggression. Personality and Social Psychology Review, 
10 (2), 111-132. doi: 10.1207/s15327957pspr1002\_2

Lemay, E. P., Overall, N. C., \& Clark, M. S. (2012). Experiences and interpersonal consequences of hurt feelings and anger. Journal of Personality and Social Psychology, 103 (6), 982-1006. doi: 10.1037/a0030064

Lersch, P. (1964). Aufbau der Person [The Composition of the Person] (9th ed.). Munich, Germany: Johann Ambrosius Barth.

Lewis, M. (1995). Shame. The exposed self. New York, NY: The Free Press.

Lewis, M., Alessandri, S. M., \& Sullivan, M. W. (1992). Differences in shame and pride as a function of children's gender and task difficulty. Child Development, 63(3), 630-638.

MacEvoy, J. P. (2006). Hurt feelings in children's friendships: associations with social cognition, behavior, and adjustment. Duke University: Unpublished doctoral thesis.

McLaren, R. M., \& Solomon, D. H. (2008). Appraisals and distancing responses to hurtful messages. Communication Research, 35 (3), 339-357. doi: $10.1177 / 0093650208315961$

McLaren, R. M., \& Solomon, D. H. (2010). Appraisal and distancing responses to hurtful messages II: A diary study of dating partners and friends.

Communication Research Reports, 27 (3), 193-206. doi: 10.1177/0093 650208315961

Mendell, D. (2002). On sulking. Psychoanalysis and Psychotherapy, 19(2), 189-197. 
Mills, R. S., Nazar, J., \& Farrell, H. M. (2002). Child and parent perceptions of hurtful messages. Journal of Social and Personal Relationships, 19(6), 731-754. doi: $10.1177 / 0265407502196001$

Mills, R. S. (2005). Taking stock of the developmental literature on shame. Developmental Re view, 25(1), 26-63. doi: 10.1016/j.dr.2004.08.001

Nielsen, M., Haun, D., Kärtner, J., \& Legare, C. H. (2017). The persistent sampling bias in devel opmental psychology: A call to action. Journal of Experimental Child Psychology, 162, 31-38. doi: $10.1016 /$ j.jecp.2017.04.017

Oster, H. (2005). The repertoire of infant facial expressions: An ontogenetic perspective. In J. Nadel \& D. Muir (Eds.), Emotional development. Recent research advances (pp.262292). Oxford, England: Oxford University Press.

Panksepp, J. (2010). The evolutionary sources of jealousy: Cross-species approaches to fundamental issues. In: S. L. Hart \& M. Legerstee (pp.101-120): Handbook of Jealousy: Theory, Research, and Multidisciplinary Approaches. West-Sussex, UK: WileyBlackwell.

Rakoczy, H., \& Schmidt, M. F. (2013). The early ontogeny of social norms. Child Development Perspectives, 7(1), 17-21. doi: 10.1111/cdep.12010

Saarni, C. (1997). Coping with aversive feelings. Motivation and Emotion, 21(1), 45-61.

Shaver, P., Mikulincer, M., Lavy, S., \& Cassidy, J. (2009). Understanding and altering hurt: An attachment-theoretical perspective on the generation and regulation of emotions. In 
A. L. Vangelisti (Ed.), Feeling hurt in close relationships (pp. 92-119). New York, NY: Cambridge University Press.

Shaver, P., Schwartz, J., Kirson, D., \& O'Connor, C. (1987). Emotion knowledge: Further exploration of a prototype approach. Journal of Personality and Social Psychology, $52(6), 1061$

Smith, C. A., \& Lazarus, R. S. (1993). Appraisal components, core relational themes, and the emotions. Cognition \& Emotion, 7 (3-4), 233-269. doi:

$10.1080 / 02699939308409189$

Sznycer, D., Tooby, J., Cosmides, L., Porat, R., Shalvi, S., \& Halperin, E. (2016). Shame closely tracks the threat of devaluation by others, even across cultures. Proceedings of the National Academy of Sciences, 201514699. doi: 10.1073/pnas.1514699113

Sroufe, L. A. (1997). Emotional development: The organization of emotional life in the early years. Cambridge: Cambridge University Press. doi: 10.1017/CBO9780511527661 
Sroufe, L. A. (2000). Early relationships and the development of children. Infant Mental Health Journal, 21(1-2), 67-74. doi: 10.1002/(SICI)1097-0355(200001/04)21:1/2<67::AIDIMHJ8>3.0.CO;2-2

Stipek, D., Recchia, S. \& McClintic, S. (1992). Self-evaluation in young children. Monographs of the Society for Research in Child Development, 95 (1).

Tronick, E., Als, H., Adamson, L., Wise, S., \& Brazelton, T. B. (1978). The infant's response to entrapment between contradictory messages in face-to-face interaction. Journal of the American Academy of Child Psychiatry, 17(1), 1-13.

Vaish, A., Carpenter, M., \& Tomasello, M. (2016). The early emergence of guilt-motivated prosocial behavior. Child Development, 87(6), 1772-1782. doi: 10.1111/cdev.12628

Vangelisti, A. L., \& Sprague, R. J. (1998). Guilt and hurt: Similarities, distinctions, and conversational strategies. In P. A. Andersen \& L. K. Guerrero (Eds.), Handbook of com munication and emotion. San Diego: Academic Press.

Vangelisti, A. L., \& Young, S. L. (2000). When words hurt: The effects of perceived intentionality on interpersonal relationships. Journal of Social and Personal Relationships, 17 (3), 393-424. doi: 10.1177/0265407500173005

Vangelisti, A. L., Young, S. L., Carpenter-Theune, K. E., \& Alexander, A. L. (2005). Why does it hurt? The perceived causes of hurt feelings. Communication Research, 32(4), 443- 477. doi: 10.1177/0093650205277319

Vingerhoets, A. J., \& Bylsma, L. M. (2016). The riddle of human emotional crying: A challenge 
for emotion researchers. Emotion Review, 8(3), 207-217. doi:

$10.1177 / 1754073915586226$

Walle, E. A., Reschke, P. J., Camras, L. A., \& Campos, J. J. (2017). Infant differential behavioral responding to discrete emotions. Emotion, 17(7), 1078-1091.

Weiner, B. \& Handel, S. J. (1985). A Cognition-Emotion-Action Sequence: Anticipated Emotional Consequences of Causal Attributions and Reported Communication Strategy. Developmental Psychology, 21(1), 102-107.

Whitesell, N.R. \& Harter, S. (1996). The Interpersonal Context of Emotion: Anger with Close Friends and Classmates. Child Development, 67(4), 1345-1359.

Williams, D. G., \& Morris, G. H. (1996). Crying, weeping or tearfulness in British and Israeli adults. British Journal of Psychology, 87(3), 479-505. 